\title{
Influence of mulching materials on fruit quality of strawberry (Fragaria ananassa Duch.) cv. CAMAROSA grown under shade net conditions of coastal Andhra Pradesh
}

\author{
S. Sujatha, V. Suchitra*, D.V. Swami, P. Subbaramamma , K. Uma Krishna and \\ L. Saravanan \\ College of Horticulture, Dr. Y.S.R. Horticultural University, Venkataramannagudem, \\ WEST GODAVARI (A.P.) INDIA (Email : varakalasuchi3@gmail.com)
}

\begin{abstract}
The effect of different mulching materials on quality of strawberry cv. CAMAROSA was studied during the year 20152016 with eight treatments replicated thrice in Randomized Block Design. The treatments comprised of coconut husk, black polyethylene, paddy straw, card board sheets, dried banana leaves, paddy husk, silver polyethylene and no mulch (Control). Among the treatments paddy straw recorded maximum TSS $\left(8.83{ }^{\circ}\right.$ Brix $)$, juice $\%(83.05 \%)$, specific gravity $\left(1.15 \mathrm{~g} / \mathrm{cm}^{3}\right)$, vitamin-C content $(58.88 \mathrm{mg} / 100 \mathrm{~g})$, total sugars $(9.50 \%)$ and minimum physiological loss in weight (13.5\% at $1 \mathrm{DAH}$ and $25.30 \%$ at $2 \mathrm{DAH})$, titrable acidity $(0.61 \%)$ and very less Albinism disorder $(0.28 \%)$ as compared to other mulching treatments and control.
\end{abstract}

Key Words : Strawberry, Quality, Total soluble solids. Total sugars, Acidity, Specific gravity

View Point Article : Sujatha, S., Suchitra, V., Swami, D.V., Subbaramamma, P., Uma Krishna, K. and Saravanan, L. (2018). Influence of mulching materials on fruit quality of strawberry (Fragaria ananassa Duch.) cv. CAMAROSA grown under shade net conditions of coastal Andhra Pradesh. Internat. J. agric. Sci., 14 (1) : 128-132, DOI:10.15740/HAS/IJAS/14.1/128-132.

Article History : Received : 18.09.2017; Revised : 19.11.2017; Accepted : 02.12.2017

* Author for correspondence: 